INTERNATIONAL JOURNAL OF RESEARCHES IN BIOSCIENCES, AGRICULTURE AND TECHNOLOGY (c) VISHWASHANTI MULTIPURPOSE SOCIETY (Global Peace Multipurpose Society) R. No. MH-659/13(N) www.vmsindia.org

\title{
BEHAVIORAL STUDY OF TWO ARANEIDAE SPIDERS FROM VIDARBHA REGION IN M.S. INDIA
}

\author{
V. B. Bhagat \\ Shri Shivaji Arts, Commerce and Science, College, Akot, M.S. India. \\ E-mail : vijaybhagat@gmail.com
}

\begin{abstract}
:
Spiders are unique in there pattern of web designing and feeding behavior. Web architecture differs significantly among spider species, ranging from the generally known orb construction to three-dimensional tangles with crossing lines of silk. This unique weaving practice of spiders attracted many scientists across the world. Present paper describes the web designing and feeding behavior of spider Neoscona theisi (Walcknaer, 1841) and Cyclosa vankhedensis (Dhande, 2017). The spiders have very small intellect but can design a very striking web for defense and feeding purpose. The gravity affects the designing of the web in the orb web waivers spiders. Investigation of orb webs of the study area showed that these vertical webs have a significant up and down asymmetry that helps them in many ways. The spiders choose their web locations with respect to availability of food, vegetation and optimum temperature. Spider shows very good feeding behavior. When any pray come in contact with the web, the spider can sense the vibration signals and orient its position towards the pray and wrap it with the help of silk and immobilize it.
\end{abstract}

Keywords: web architecture, spider, behavior, gravity, feeding

\section{INTRODUCTION:}

Spiders are excellent organisms for their web building behavior in the terrestrial ecosystem than any other invertebrate. The spiders from family araneidae are orb web waivers as they construct web on different herbs, shrubs, and on grasses in different ecological niches. Several aspects of orb web design have been thought to be specific or genus specific (Savory 1952; Witt and Baum 1960; Reed and Jones 1965; Witt et al 1968; Risch 1977).The spiders are usually resting motionless in the hub or on nearby vegetation while connected to the hub through a signal thread from where they will initiate prey attack behaviour when vibratory signals from the struggling prey reach the hub via the radii (Masters et al., 1986; Landolfa and Barth, 1996).Web-building spiders in general and orbweb spiders in particular are excellent model organisms for studies of cognitive abilities in terrestrial non-insect invertebrates since they leave a physical record, i.e. the web of their foraging behaviour (Vollrath and Selden, 2007). In most webs, the hub is not located in the exact centre of the web, but usually displaced upwards to give asymmetric webs with a larger lower part reflecting the fact that spiders, due to gravity, can run faster downwards than upwards (A P Rhiziart and Vollrath, 1994; Zschokke and Nakata, 2010).Spiders from family araneidae constructs web in different vegetation and use the silk produced by silk gland in the feeding process. It has been observed that when they feel vibrations, they orient themselves towards the prey and attack by wrapping the prey with the silk, paralyse it and finally feed on it

\section{MATERIAL AND METHOD:}

Study area- The study was conducted during February 2016 to January 2017 in Akola district of Indian state, Maharashtra. The city of Akola is the district head quarters. Akola district forms the central part of Amravati Division. The climate is tropical and annual temperatures range from a high of $48^{\circ} \mathrm{C}\left(118^{\circ} \mathrm{F}\right)$ to a low of $10^{\circ} \mathrm{C}\left(50^{\circ}\right)$. Akola is situated on the Tropic of Cancer and becomes hot during the summer season, especially in the month of May. Although it can be very hot during the day but it is cool during night. The annual rainfall averages $850 \mathrm{~mm}$. Most of the rainfall occurs in the monsoon season between June and 
September, but some rain does fall during January and February.

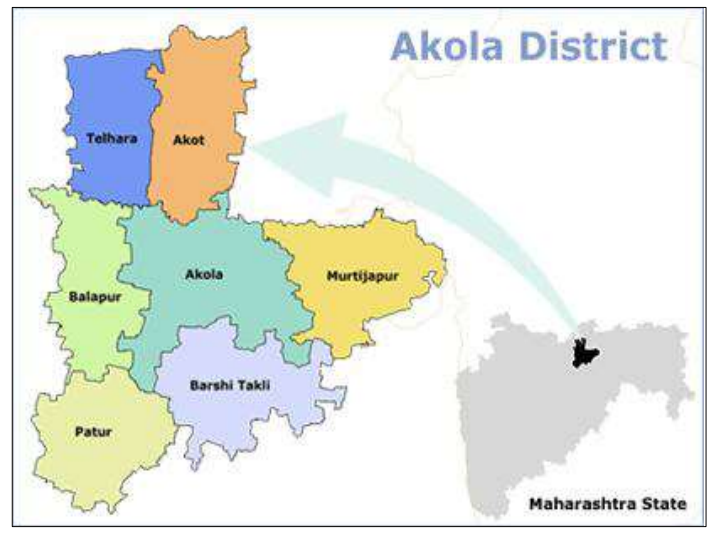

Fig.1.Map of Akola District

\section{METHODOLOGY -}

Site identification- The suitable site which is diverse in vegetation is selected to study web designing behavior of spiders.

Spider web identification- The web consist of spider sitting in the hub were selected for the study. The different web designing behaviour such as sitting position, selected vegetation, type of pray captured, distance of the web from ground, effect of temperature on the spider behaviour by taking their pictures and comparing and analyzing them with the of previous work

Spider feeding behavior- The methodology used for the present paper is of primary nature. First of all, a site was selected to locate the species of desired spider. Secondly, we have re a video of studied spider for its feeding behavior. Further its behavior has been keenly observed through the video and at least feeding pattern is brought to the fore. However, the methodology is also of sampling type and observatory

Photography. To know each web designing behaviour, photograph were taken by using super-macro lens of Canon camera.

\section{RESULT AND DISCUSSION:}

Web building behavior of Neoscona theisi-The spiders Neoscona theisi (Walcknaer, 1841) is orb web weavers as they show a very beautiful web building ability. They construct vertical web in the morning as well as in the evening which lies 4-10 feet away from the ground. The young spider has greater speed of web designing than adult. The orb web constructed in between the branches consists of a hub from which silk threads radiate towards the frame that connects to the branches and leaves through anchor threads. The spider sits in the centre of the hub oriented head downward to the ground. When receive signals of vibration from the silk treads they initiate prey attack behaviour of pray captured in the web. It has been observed that the spider also initiate pray attach behaviour even on capturing of small non living objects.

\section{Web building behaviour of Cyclosa vankhedensis -}

The spiders Cyclosa vankhedensis (Dhande, 2017) is orb web waiver and construct vertical web in the bushes and long grasses along the crop land and road sides nearby agriculture vegetation. Female sitting position is specific oriented dorsal position towards the vegetation. The web lies 1-8 feet and way platform the ground. Orb web are constructed in two

dimensional structures in highly regular geometry. In sacs few web the prey remains, eggs, plant debris observed. The spider sits in the centre of the web decoration containing pray remains and other debris that help them to hide. When receive signals of vibration from the silk treads they initiate prey attack behaviour of pray captured in the web. When get disturbed by external object they hide for certain period in the foliage. 

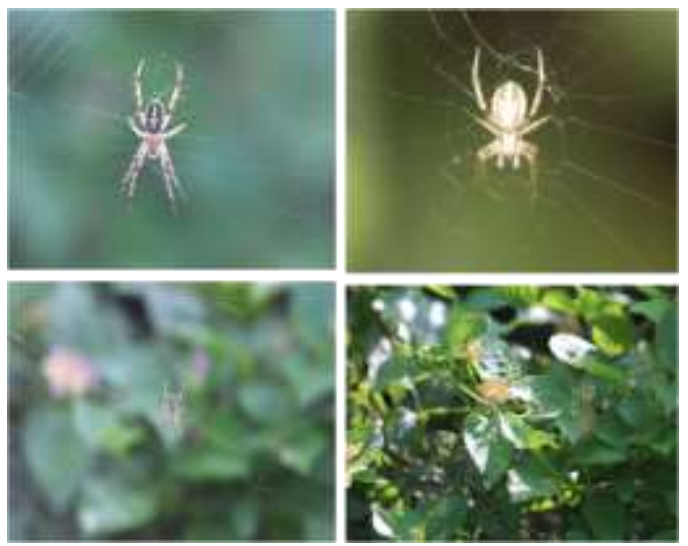

Fig: 2. Spider sitting in the centre of hub region. B. Female Spider in the irregular web toward vegetation $C$. Female spider in the web D. Vegetation where spider construct web
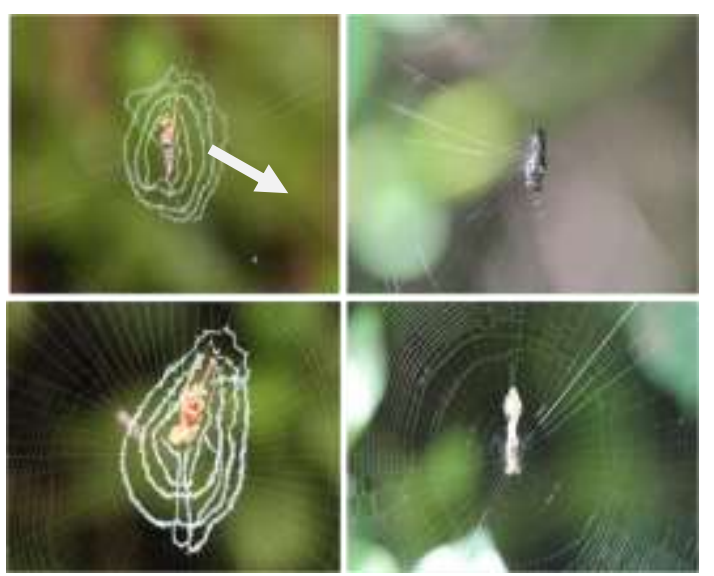

Fig: 2.1 A. Spider sitting in the centre of decorated web. B. Female spider in the web toward vegetation $\mathrm{C}$. Spider moving to hide when get disturb D. Spider in the web decoration containing pray remain and other debris that help them to hide and resting.

\section{Feeding behavior -}

When any pray come in contact with the web, the spider can sense the vibration signals and orient its position towards the pray and wrap it with the help of silk and immobilize it. When the pray is small it is carried by the spider away from the web to branches to

paralyze by poisonous gland and feed on it. Many of the time it again comes to the web for feeding. The web get disturb during the catching of the pray. They can capture the pray 5-6 times larger than its size.
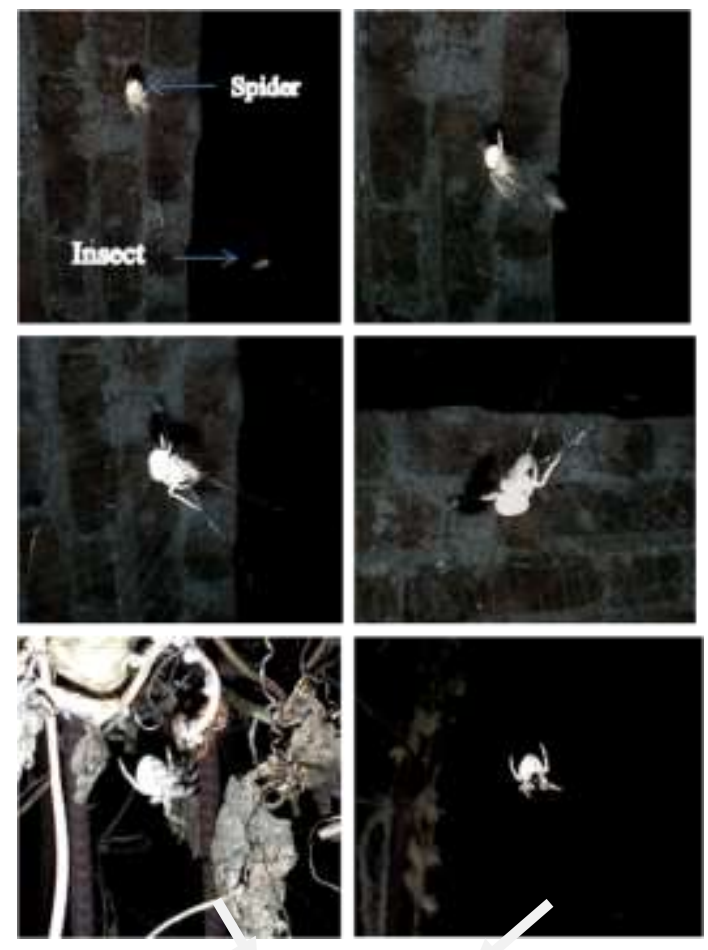

Fig.3. Flying insect trapped in spider web 2. Spider has sensed vibrations produced by insect and orient its position toward insect 3, 4. Spider paralyzed insect by poisonous gland 5 . Spider carried insect to the branches of plant nearby for feeding 6. Spider returns back to the web with insect for feeding

\section{REFERENCES:}

Dhande, S. S., Bodkhe, A. and Ahmad, R. I, 2017. Desci: tion of a new spider species

in

the genus Cyclosa (Araneae- Araneidae) from India. Trends in Biosciences 10(20): 3825-3831

Landolfa, M. A., and Barth, F. G, 1996. Vibrations in the orb web of the spider Nephilaclavipes: Cues for discrimination and orientation. Journal of Comparative Physiology 179: 493-508.

Masters, W. H, Markl, H. S, and AJM, Moffat, 1986. Transmission of vibration in spider, web. In WA Shear, ed. Spiders: 
webs, behavior and evolution. Stanford, CT: Stanford Univ. Press, pp. 49-69

Rhiziart, A. P, F., and Vollrath, 1994. Design features of the orb web of the spider, Araneusdiadematus. BehavEcol 5; 280-287

Reed, C. F., P. N, Witt, and R, L.Jones, 1965. The measuring function of the first legs of Araneusdiadematus CL. Behaviour 25: 98-119.

Risch, P., 1977. Quantitative analysis of orb web patterns in four species of spiders. Behav. Genet., 7: 199-238.

Savory, T. H, 1952 . The Spider's Web . Frederick Warne, London .

Vollrath, F, Selden P, 2007. The role of behavior in the evolution of spider, silks and webs. Annual Review of Ecology, Evolution and Systematics 38: 819846.

Walckenaer, C. A, 1841. Histoire naturelle des Insects. Aptères. Tome deuxième. Roret, Paris, 549 pp., pl. 16-22
Witt, P. N, and Baum, R, 1960. Changes in orb web of spiders during growth (AraneusdiadematusClerck and Neoscona vertebrata McCook). Behaviour, 16: 309-318.

ApRhisiart A, Vollrath F (1994) Design features of the orb web of the spider, Araneusdiadematus. BehavEcol 5:280-287

ApRhisiart A, Vollrath F (1994) Design features of the orb web of the spider, Araneusdiadematus. BehavEcol 5:280-287

ApRhisiart A, Vollrath F (1994) Design features of the orb web of the spider, Araneusdiadematus. BehavEcol 5:280-287

ApRhisiart A, Vollrath F (1994) Design features of the orb web of

the spider, Araneusdiadematus. BehavEcol 5:280-287

Zschokke, S, and Nakata, K, 2010. Spider orientation and hub position in orb web. Naturwissenschaften 97: 43-52. 